\title{
Biological observations on the Bengal guitarfish Rhinobatos annandalei Norman, 1926 from the Eastern Arabian Sea, India
}

\author{
G. B. PURUSHOTTAMA, V. RAMASUBRAMANIAN*, K. V. AKHILESH, S. G. RAJE, \\ THAKURDAS, SHOBA JOE KIZHAKUDAN AND P. U. ZACHARIA \\ ICAR-Central Marine Fisheries Research Institute, P. B. No. 1603, Ernakulam North P. O., Kochi - 682018 \\ Kerala, India \\ *ICAR-Indian Agricultural Statistics Research Institute, Library Avenue, Pusa, New Delhi - 110 012, India \\ e-mail:puru44@gmail.com
}

\begin{abstract}
Biological data for the little known Bengal guitarfish Rhinobatos annandalei Norman, 1926 (Rhinopristiformes: Rhinobatidae) are presented based on specimens collected from bycatch of commercial shrimp trawlers, gill netters and bag or dol netters operating in the Arabian Sea at depths of 2-70 $\mathrm{m}$ off the north-west coast of India. Five hundred ninety three specimens measuring 30.0 to $95.0 \mathrm{~cm}$ total length (TL) and weighing between 64.0 to $3300 \mathrm{~g}$ total weight (TW) were collected for the study. The length-weight relationships (LWR) were significantly different between the sexes $(\mathrm{p}<0.001)$ and the LWR for the combined sexes was derived as $T W=0.000604 \mathrm{TL}^{3.408256}\left(\mathrm{r}^{2}=0.997\right)$. The co-efficients ' $a$ ' and ' $b$ ' of the LWR were estimated as $0.000621,3.410115\left(r^{2}=0.999\right)$ for females and $0.000766,3.333872\left(r^{2}=0.999\right)$ for males. The length at maturity $\left(\mathrm{TL}_{50}\right)$ for females and males was estimated to be 61.0 and $63.3 \mathrm{~cm} \mathrm{TL}$, respectively. In a single female, the number of embryos ranged from 2 to 11 and the size at birth was estimated between 25.0 to $30.0 \mathrm{~cm}$ TL. The overall sex ratio favoured females at the rate of 1.6:1. An analysis of the stomach contents (\%IRI) revealed that $R$. annandalei mainly fed on Solenocera spp. (18.7\% IRI), along with P. sculptilis (0.5\% IRI), P. stylifera (0.4\% IRI), Loligo spp. (0.4\% IRI) and sciaenids $(0.3 \%$ IRI). Since, the species is poorly studied and assessed as 'Data Deficient' in the IUCN red list criterion, it is anticipated that the biological results from the present study, will update information on the species thereby enabling more effective management decisions.
\end{abstract}

Keywords: Arabian Sea, Diet, Length at maturity, Length-weight relationship, Reproductive biology, Rhinobatos annandalei

\section{Introduction}

Shovelnose rays (guitarfishes) of the family Rhinobatidae (Rhinopristiformes) represented worldwide by 3 genera and about 31 species, is most diverse in the Indo-West Pacific (Last et al., 2016). All the batoids, especially Rhinopristiformes are considered to be at high risk of extinction in certain parts of the world and in view of this, a proposal to include all of them in the CITES annex is in the process (Moore, 2017). The Bengal guitarfish, Rhinobatos annandalei Norman, 1926, currently has a distribution range from Sri Lanka, India, Pakistan and also possibly from the Gulf (Last et al., 2016; Jabado, 2018). It is classed in the IUCN red list threatened species as data deficient (DD) (Valenti, 2009). Raje (2006) reported that $R$. annandalei is caught as bycatch in shrimp trawls, the landing of which had increased from nil during 1989-1993 to $0.26 \mathrm{t}$ in 1994-1998 and later to $7.56 \mathrm{t}$ in $1999-2003$. However, the average annual landings decreased to $1.8 \mathrm{t}$ during 2012-2016 (CMFRI, 2013; 2014; 2015; 2016). Though forming a fishery component in its distribution range, knowledge of its life history is poor and limited to a few studies in the north-eastern Arabian Sea (Vossoughi and Vosoughi, 1999; Raje, 2006; Raje et al., 2012; Jabado, 2018). Further, most of these studies are restricted to either length frequency or length-weight relationships and do not elicit details regarding its reproductive biology or diet. Therefore, understanding the species composition of landings and the biological traits of exploited shark-like batoids is crucial for the development and implementation of effective management and conservation strategies for them in Indian waters.

Elasmobranch fisheries demand vigilant management strategies that support sustainable and continuous harvest, while ensuring that the resource is not overexploited and avoids adverse impact on the ecosystem and extinction risk (Moore et al., 2012; Jabado et al., 2017; Jabado, 2018; Jabado et al., 2018). Guitarfishes have been identified as being amongst the most vulnerable of the elasmobranch families, after sawfishes (Dulvy et al., 2014; Moore, 2017). Its vulnerability is further compounded by limited information on its reproductive biology, diet and stock assessment in the northern Indian 
Ocean. For this reason, the present study aims to perceive the reproduction, maturity, length-weight relationship and diet characteristics of $R$. annandalei caught along the north-west coast of India, in the northern Indian Ocean and to provide detailed information on its life history traits.

\section{Materials and methods}

A total of 593 specimens of $R$. annandalei were collected from the bycatch landings of commercial shrimp trawlers, gillnetters and bag or dol netters operating in the northern Arabian Sea during 2012-2016 at 2-70 m depth and landed at the New Ferry Wharf $\left(18^{\circ} 57^{\prime} 28.85^{\prime \prime} \mathrm{N} ; 7^{\circ}\right.$ $51^{\prime} 02.73$ " E), Sassoon Docks (18 ${ }^{\circ} 54^{\prime} 42.43^{\prime \prime} \mathrm{N} ; 72^{\circ} 49^{\prime}$ 33.16” E), Satpati (19०43'30.75" N; $72^{\circ} 42^{\prime}$ 08.30” E and at Alibaug $\left(18^{\circ} 38^{\prime} 4.25^{\prime \prime} \mathrm{N} ; 72^{\circ} 52^{\prime} 38.95^{\prime \prime} \mathrm{E}\right)$ fishing harbours along Maharashtra coast (Fig. 1).

The total length (TL) of each specimen was measured to the nearest $\mathrm{mm}$ and the total body weight (TW) to the nearest $g$ and after recording the sex, the specimens were categorised based on TL and umbilical scar. The umbilical scar was assessed based on the healing stage (e.g. open, healing, or closed). The opened and healing umbilical scars characterise the neonate period, while the closed scars denote juveniles. The weekly length frequency data of $R$. annandalei collected were raised to the monthly and annual figures using the Stratified Random Sampling technique (Alagaraja, 1984).

The length-frequency distribution was tested for normality using the Shapiro-Wilk test. As the data followed normal distribution, size differences between females and males were tested using the two-tailed $t$-test. This was to ascertain any sex-based differences in landings. The sizefrequency distribution of females and males was compared using the $\chi^{2}$ test with the size distribution divided into 5.0 $\mathrm{cm}$ class intervals of TL (Cochran, 1952). To test sex ratios being at parity, the two sided exact ratio test was employed (Biradar, 2002). The seasonal sex ratio was estimated considering three seasons, namely, pre-monsoon (February-May), monsoon (June-September) and postmonsoon (October-January).

The sex and maturity stages were examined using the maturity scale proposed by Stehmann (2002), based on the ovarian and uterine condition for females and clasper calcification for males. For calculation of length at maturity $\left(\mathrm{TL}_{50}\right)$ for females and males, the specimens were classed as either immature (uncalcified or partially calcified claspers for males and ovaries not developed or with maturing oocytes, but uteri thin and ribbon-like for females) or mature (claspers fully calcified; ovaries and uteri both fully developed). For males, the outer clasper length (OCL) was recorded to establish clasper length $v s$. size relationship.

The $\mathrm{TL}_{50}$ for females and males was derived from the following logistic regression, where the proportion $(\mathrm{pL})$, of guitar fishes that were mature at TL was calculated as: $\left.\left.\mathrm{pL}=\left\{1+\mathrm{e}^{[-\ln (19)(\mathrm{TL}-\mathrm{TL}}\right)_{50}\left(\mathrm{TL}_{95}{ }^{-\mathrm{TL}}{ }_{50}\right)\right]^{-1}\right\}^{-1}$, where $\mathrm{TL}_{50}$ and $\mathrm{TL}_{95}$ are constants and $\mathrm{ln}$ is the natural logarithm (Wood, 2004; White, 2007, Purushottama et al., 2017). Maximum likelihood estimates of the parameters were obtained using the routine SOLVER in Microsoft ${ }^{\mathrm{TM}}$ Excel and by calculating the likelihood of immature and mature individuals as $1-\mathrm{pL}$ and $\mathrm{pL}$, respectively. The

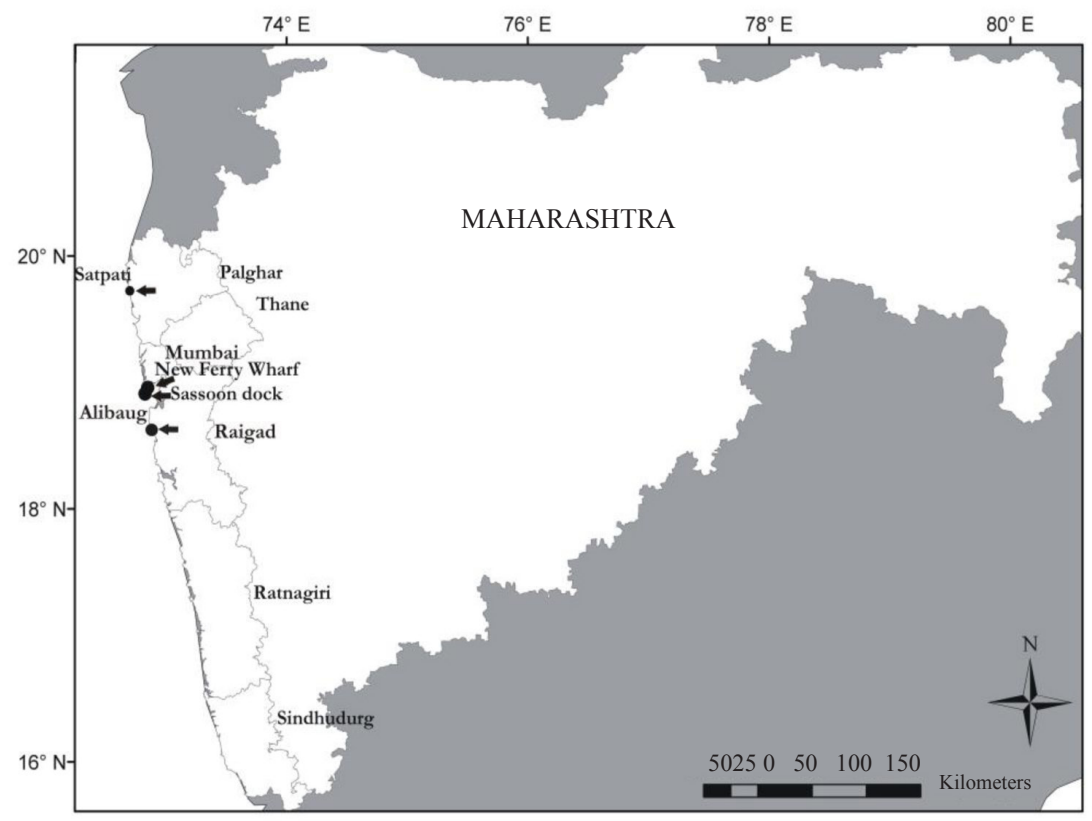

Fig. 1. Map showing $R$. annandalei sampling sites 
reported estimates of the parameters were determined as the median values derived from 200 sets of randomly re-sampled data, with the same sample size, drawn from the data on the observed maturity status at TL for female and male guitarfishes. The c. $95 \%$ C. I. was estimated as 2.5 and 97.5 percentiles of the 200 estimates resulting from these re-sampled data.

The parameters ' $a$ ' and ' $b$ ' of the length-weight relationships (LWR) were estimated using the equation proposed by Le Cren (1951): TW= $a * \mathrm{TL}^{\mathrm{b}}$. After logarithmic transformation of the length and weight data, this equation may be expressed as: $\log \mathrm{TW}=\log a+b^{*}$ $\log$ TL; where, TW is the weight of the fish in $g$ and TL is the total length of the fish in $\mathrm{cm}, a$ is the intercept of the regression curve (coefficient related to body form) and $b$ is the regression coefficient (exponent indicating isometric growth; Froese, 2006). The confidence and prediction intervals were calculated for the length and weight of the guitarfish in the LWRs using the following formulae: the confidence interval for the mean response when predictor is $\mathrm{x} *$ is $\hat{\mathrm{y}} \pm \mathrm{t} * S \in \sqrt{ } 1 / \mathrm{n}+(\mathrm{x} *-\mathrm{x})^{2} /(\mathrm{n}-1) s_{\mathrm{x}}^{2}$ and the prediction interval for an individual response when the predictor is $\mathrm{x}^{*}$ is $\hat{\mathrm{y}} \pm \mathrm{t}^{*} S \epsilon \sqrt{ } 1+1 / \mathrm{n}+\left(\mathrm{x}^{*}-\mathrm{x}\right)^{2} /(\mathrm{n}-1) s^{2}{ }_{\mathrm{x}}$ (Montgomery et al., 2012). The male and female LWR was tested for significant difference using the extra sum of squares method involving full and reduced regression models for testing the common slope (parallel lines), while the $F$-statistic was computed to test the difference between the two slopes (Montgomery et al., 2012).

Equations for the relationship between size and weight were obtained by fitting a power curve of the form $\mathrm{y}=\mathrm{ax}^{\mathrm{b}}$ using Microsoft ${ }^{\mathrm{TM}}$ Excel. For those species for which an equation for the relationship between size and weight was calculated, the weight of each individual measured but not weighed was calculated using the above equation for that particular species. For each species, the weight of those individuals recorded but without a size measurement were estimated by obtaining an average weight of individuals for that species using the above methodology. Total weight was then determined for each batoid species.

To describe the diet, percent frequency of occurrence $(\% O)$, percent composition by number $(\% N)$ and percent composition of weight $(\% W)$ was used to estimate the percent index of relative importance $(\% \mathrm{IRI})$ as IRI $=(\% \mathrm{~N}$ $+\% \mathrm{~W}) * \% \mathrm{O}$ (Pinkas et al., 1971). The IRI was expressed as \%IRI to allow for a comparison of the values between the prey groups (Cortes, 1997).

\section{Results}

Species composition of Rhinopristiformes

Families Rhinidae, Rhinobatidae and Pristidae were observed at the fish landing centres visited in Maharashtra as eight taxonomically defined species and one Rhynchobatus sp., which contributed $41.1 \%$ to the total biomass of the batoidea (Table 1). R. annandalei contributed only $3.5 \%$ to the total biomass of all batoidea. The present investigation was not only limited to biological studies, but also quantitative assessment of the resources was undertaken to ascertain the landings in Maharashtra on the north-west coast of India. However, it was observed that Bengal guitarfish constituted about $2 \%$ of the total catch of batoidea landings in Maharashtra region. The estimated annual landings (2012-2016) of $R$. annandalei by shrimp trawlers, gillnetters and bag or $d o l$ netters together as bycatch was higher in 2016 (3.1 t) and $2015(3.0 \mathrm{t})$, but much lower in the three previous years, i.e. $0.1 \mathrm{t}$ in 2012, $0.2 \mathrm{t}$ in 2014 and $0.6 \mathrm{t}$ in 2013. Thus, there was 40 times increase in landings in 2016 compared with 2012.

Table 1. Percentage contribution by biomass $(\% \mathrm{~B})$ and minimum and maximum total length (TL) of each species of shark-like batoids recorded at fish landing centres in eastern Arabian Sea

\begin{tabular}{lllll}
\hline Species & Common name & $\% \mathrm{~B}$ & \multicolumn{2}{c}{ TL $(\mathrm{cm})$} \\
\cline { 4 - 5 } & & 41.1 & & Minimum \\
\hline Shark-like batoids & & 3.5 & 30.0 & 95.0 \\
Rhinobatos annandalei & Bengal guitarfish & 16.6 & 28.0 & 231 \\
Rhina ancylostoma & Bow mouth guitarfish & 41.4 & 44.0 & 290 \\
Rhynchobatus spp. & Wedge fishes & 14.0 & 55.0 & 235 \\
Rhynchobatus australiae & Bottlenose Wedge fish & 15.0 & 58.0 & 259 \\
Rhynchobatus laevis & Smoothnose Wedge fish & 0.6 & 58.0 & 154 \\
Glaucostegus granulatus & Granulated guitarfish & 0.1 & $\mathrm{NA}_{\text {min }}$ & 65.0 \\
Glaucostegus halavi & Halavi guitarfish & 1.0 & 26.5 & 101 \\
Glaucostegus obtusus & Grey guitarfish & 7.8 & $\mathrm{NA}_{\min }$ & 400 \\
Pristis pristis & Large tooth sawfish & $37387 \mathrm{~kg}$ & & \\
\hline Total (of all batoidea recorded) & & &
\end{tabular}

$\mathrm{NA}_{\min }$ : Minimum size not available 


\section{Sex and size distribution}

Commercial shrimp and fish trawlers, gillnetters and bag or dol netters land Bengal guitarfish as bycatch along Mumbai, Palghar and Raigad in Maharashtra region throughout the year, except during the south-west monsoon due to rough weather and uniform mechanised fishing ban by the Government of India on the west coast from June 01 to July 31 . The number of sampled specimens ranged from 14 in December 2012 to 195 in September 2016 (Pooled data).

Overall 593 specimens of $30.0-95.0 \mathrm{~cm}$ TL (mean \pm SD $=56 \pm 18 \mathrm{~cm})$ and weighing between 68.0 to $3300 \mathrm{~g}$ (mean $\pm \mathrm{SD}=805 \pm 705 \mathrm{~g}$ ) in case of females and of 30.0 to $95.0 \mathrm{~cm}$ TL (mean $\pm \mathrm{SD}=48 \pm 15 \mathrm{~cm}$ ) and weighing between 64.0 to $2961 \mathrm{~g}$ (mean $\pm \mathrm{SD}=435 \pm 364 \mathrm{~g})$ in case of males were observed to attain similar maximum size.

The monthly length frequency distribution (pooled years) did not present clear trends for females and males (Fig. 2a-j). The landings were represented by a wide size range of specimens in all the months for which the data was obtained. Of these, fourteen size classes $(5.0 \mathrm{~cm}$ TL intervals) were used for length classification, from 30.0 to $95.0 \mathrm{~cm}$ TL (Fig. 3). The $\chi^{2}$ test revealed significant difference $(\mathrm{p}<0.001)$ in length frequency distribution with more females caught in the size class $65.0-85.0 \mathrm{~cm}$ TL and most males caught in the size class $50.0-75.0 \mathrm{~cm}$ TL.

The overall sex ratio (F:M) in the landings was 1.6:1 in favour of females, which significantly deviated from the expected ratio of $1: 1(p<0.05)$. The seasonal sex ratio was estimated considering three seasons. The pre-monsoon (February-May) sex ratio was $0.8: 1$, for monsoon (JuneSeptember) it was 2.8:1 and in post-monsoon (OctoberJanuary) it showed 1.4:1. The distribution of females and males of $R$. annandale $i$ was significantly different in the sampling months $\left(\chi^{2}\right.$, d.f. $\left.=9 ; \mathrm{p}<0.001\right)$.

The distribution of the number of females and males differed significantly in the different sub-groups viz., juveniles, sub-adults and adults $\left(\chi^{2}\right.$, d.f. $\left.=2, p<0.001\right)$. The sex ratio of female to male in juveniles $(<50 \mathrm{~cm}$ TL), sub-adults $(51-63 \mathrm{~cm} \mathrm{TL})$ and adults $(>63 \mathrm{~cm} \mathrm{TL})$ was $0.97: 1,0.62: 1$ and $4.1: 1$, respectively.

The distribution pattern of $R$. annandalei (females and males) juveniles, sub-adults and adults in different months (pooled data) showed that juveniles $(<50 \mathrm{~cm}$ TL) were observed maximum in January (19\%), March (18\%) and May (17\%); sub-adults (51-60 cm TL) in August (30\%) and September (28\%) and adults $(>61 \mathrm{~cm}$ $\mathrm{TL})$ accounted for maximum in September (58\%) and
August (24\%) for female (Fig. 4a). In the case of males, juveniles $(<50 \mathrm{~cm}$ TL) appeared in January-May and peaked in February (20\%), sub-adults (51-62 cm TL) in August (22\%) and September (32\%) and adults $(>63 \mathrm{~cm}$ TL) between September and August with the highest in September (44\%) (Fig. 4b).

\section{Length-weight relationships}

The weight of $R$. annandalei ranged between 68.0 to $3300 \mathrm{~g}$ in females and between 64.0 to $2961 \mathrm{~g}$ in males. The equations relating to total length (TL) and weight (TW) (TL v. TW) consisting of 251 females (30.0 -95.0 $\mathrm{cm}$ TL) and 183 males (30.0-95.0 $\mathrm{cm}$ TL) are presented below, thus enabling an approximate weight of the Bengal guitarfish to be estimated from a given total length (Fig. 5a, b, c). The slopes were found to be significantly different between the sexes $(\mathrm{p}<0.001)$.

$$
\begin{aligned}
& \text { Females: } \mathrm{MT}=0.000621 \mathrm{TL}^{3.410115}\left(\mathrm{r}^{2}=999,95 \%\right. \text { C.I. of } \\
& b=3.239609-3.580621, n=251) \\
& \text { Males: } \mathrm{MT}=0.000766 \mathrm{TL}^{3.333872}\left(\mathrm{r}^{2}=0.999,95 \% \text { C.I. of } b=\right. \\
& \text { 3.167178-3.500566, } n=183)
\end{aligned}
$$

There was significant difference between the length and weight relationship of the females and males ( $t$-test, d.f. $=591, \mathrm{p}<0.001)$. For females and males, the average length and weight were significantly different in all the sampling months $\left(\chi^{2}\right.$, d. f. $\left.=9, \mathrm{p}<0.001\right)$.

\section{Reproductive biology}

A total of 593 (females $=367$; males $=226$ ) samples were used for the reproductive biology studies. Mature females, with ovaries containing maturing oocytes (maximal ovarian fecundity) ranged from one to eleven (mean $+\mathrm{SD}=8.0 \pm 2.7)$ and oocyte diameter measuring 5.1 $\mathrm{mm}$ to $39 \mathrm{~mm}\left(\right.$ mean $\left._{-} \mathrm{SD}=21.1 \pm 7.5\right)$. Functional uteri, were observed in specimens of 65.0 to $95.0 \mathrm{~cm}$ TL. The largest immature female measured $74 \mathrm{~cm}$ in TL. The female $R$. annandalei matured between 60 and $65 \mathrm{~cm}$, with $50 \%$ maturity occurring at $61.0 \mathrm{~cm}$ TL (95\% C.I) (Fig. 6a). The smallest mature male $R$. annandalei recorded was of $61 \mathrm{~cm} \mathrm{TL}$ and the largest immature male was $65 \mathrm{~cm}$ in TL. The males matured in different size range (60-65 $\mathrm{cm}$ ) and $50 \%$ maturity occurred at $63.3 \mathrm{~cm}$ TL (95\% C.I.) (Fig. 6b).

The claspers of male $R$. annandalei are elongated and rigid at approximately $55 \mathrm{~cm} \mathrm{TL}$ and most of the examined samples were fully calcified at $>60 \mathrm{~cm}$ TL. Sizes of maturity classes for $R$. annandalei were $<50 \mathrm{~cm}$ TL $(28.3 \%, n=104)$ for juveniles, between 51-60 cm TL $(10.9 \%, n=40)$ for sub-adults and $>61 \mathrm{~cm}$ TL for mature 


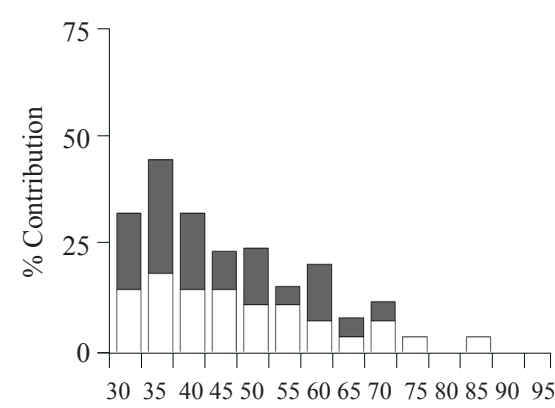

(a)

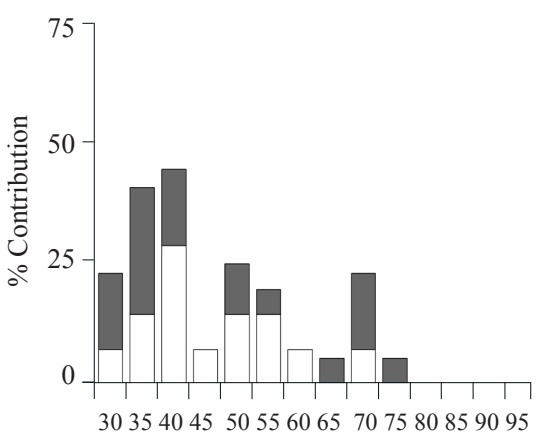

(d)

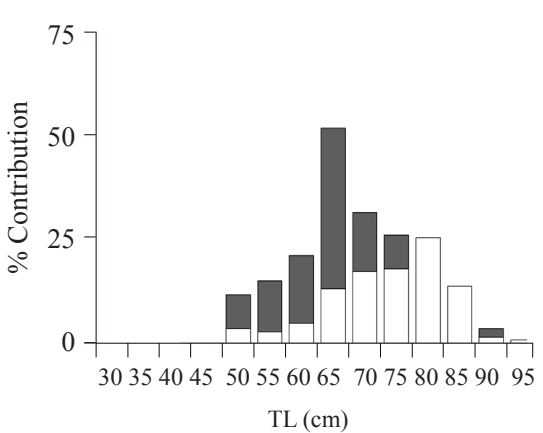

(g)

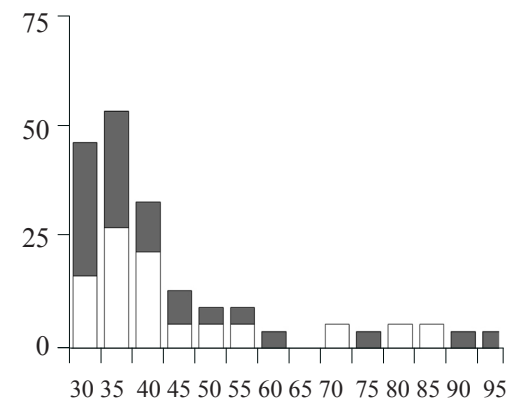

(b)

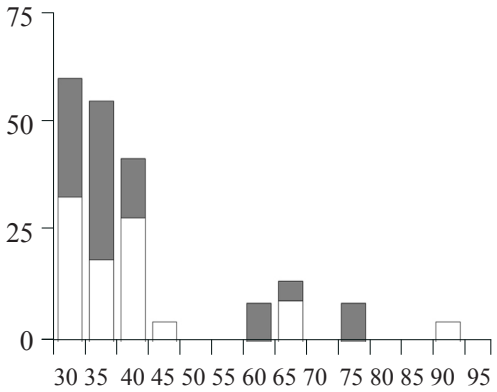

(e)

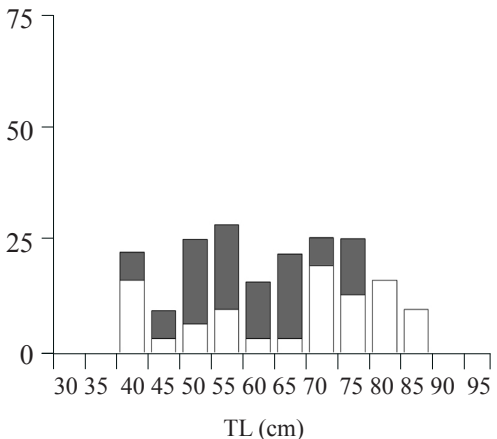

( h)

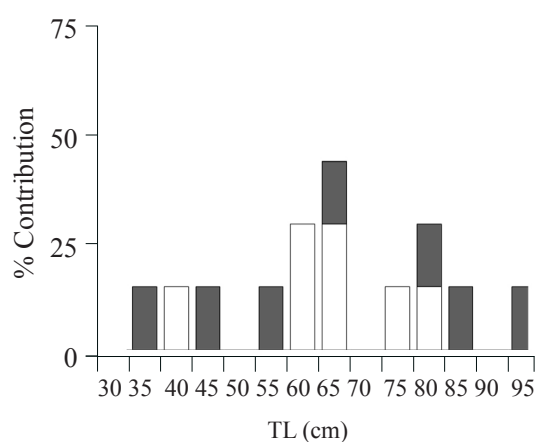

(j)

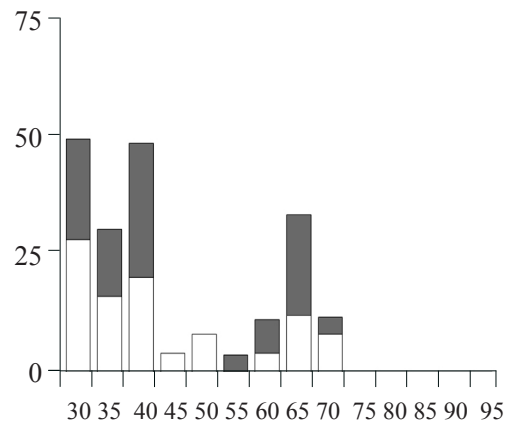

(c)

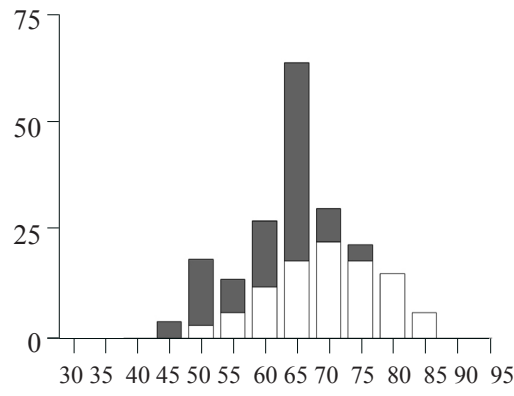

(f)

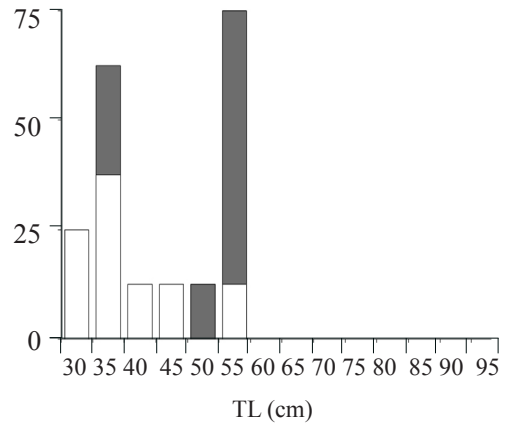

(i)

Fig. 2. Monthly total length (TL)-frequency histograms for females ( $\square$ ) and males $(\square)$ of $R$. annandalei from Maharashtra between January 2012 to December 2016. Data pooled over the five years for (a) January, (b) February, (c) March, (d) April, (e) May, (f) August, (g) September, (h) October, (i) November, (j) December 


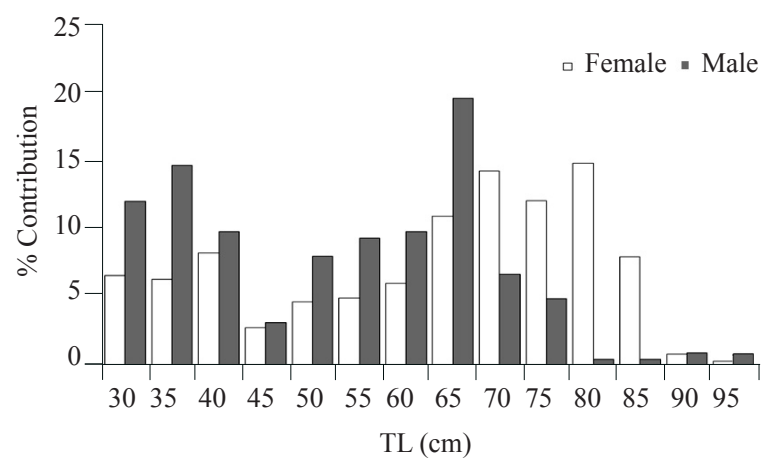

Fig. 3. Total length (TL)-frequency histogram of $R$. annandalei. Females $(\square) n=367$; Males $(\square) n=226$

adult $(60.8 \%, n=223)$ in case of females and $<50 \mathrm{~cm}$ TL $(47.3 \%, n=107)$ for juveniles, between $51-62 \mathrm{~cm}$ TL for sub-adults $(28.8 \%, n=65)$ and $>63 \mathrm{~cm}$ TL for mature adult $(23.9 \%, n=54)$ of males. The classification was done based on $50 \%$ maturity $\left(\mathrm{TL}_{50}\right)$.

One hundred eight pregnant females of $R$. annandale $i$ $(68.0-84.2 \mathrm{~cm} \mathrm{TL}$; mean $\pm \mathrm{SD}=72.6 \pm 3.6 \mathrm{~cm})$ were dissected and it was found that each contained two to eleven (mean $\pm \mathrm{SD}=2.3 \pm 1.2$ ) fully formed embryos of 25.0-30 $\mathrm{cm}$ TL $($ mean $\pm \mathrm{SD}=25.5 \pm 3.2 \mathrm{~cm})$, weighing between 50.0 to $58.0 \mathrm{~g}($ mean $\pm \mathrm{SD}=53 \pm 3.5 \mathrm{~g})$. The reproductive mode was aplacental viviparity. The size-frequency distribution of pregnant $R$. annandalei is presented in Fig. 7. The pregnant females were observed in all months and exhibited a non-seasonal reproductive cycle. Maximum pregnant females were observed in the length classes of $66.0-70.0 \mathrm{~cm}$ TL, 71.0-75.0 cm TL, 76.0-80.0 $\mathrm{cm}$ TL and $81.0-85.0 \mathrm{~cm}$ TL(Fig. 8). Near-term embryos, ranging in size from $20.0-25.0 \mathrm{~cm}$ TL, had a yolk-sac stalk still attached and the late term (near to parturition) embryos of 25.0-30.0 cm TL were found to have an umbilical scar. The smallest specimen observed in the fishery was $30 \mathrm{~cm} \mathrm{TL}$, however, the number of newborn/juveniles observed in the gillnet catch was very low (in the dol or bag netter and trawler landings at Maharashtra, a number of newborns of 30.0-35.0 cm TLwere observed). Based on the current dataset, the size at birth of $R$. annandale $i$ in the north-west coast of India was estimated to range from 25.0 to $30.0 \mathrm{~cm}$ TL. The greatest number of embryos i.e., 12 (left 6 and right 6 ) of mean size $10.6 \mathrm{~cm}$ TL and sex ratio of 0.8:1 (female: male) was recorded for $R$. annandalei of $82.5 \mathrm{~cm}$ TL and weighing $2000 \mathrm{~g}$. The overall sex ratio within the embryos in the 201 litters (from 108 females) studied was not significantly different from parity (d.f. $=1$, $\mathrm{p}>0.05$ ) and the sex ratio of the embryos was observed to be $1.2: 1$ (female to male), with the largest embryos observed being of $30.0 \mathrm{~cm}$ TL in case of females and 29.5 $\mathrm{cm}$ TL for males. The OCL of the smallest male was 1.9 $\mathrm{cm}$ (specimen of $30.0 \mathrm{~cm} \mathrm{TL}$ ), while that of the largest was $11.3 \mathrm{~cm}$ (specimen of $95.0 \mathrm{~cm} \mathrm{TL}$ ) and there was noticeable increase in OCL with TL (Fig. 9).

\section{Feeding habit}

A total of 357 specimens $(40.0-95.0 \mathrm{~cm}$ TL) were examined for understanding the prey selection of $R$. annandalei. Of these, only 30\% $(n=107)$ contained prey items and were analysed for the index of relative importance (IRI), 26.0\% $\quad(n=92)$ contained either semi-digested or highly digested and trace food that could not be identified and $44.0 \%(n=157)$ were empty. The fullness of the stomach revealed that $4.5 \%(n=16)$ were a quarter full, $15.7 \%(n=56)$ were a half full, $30.3 \%$

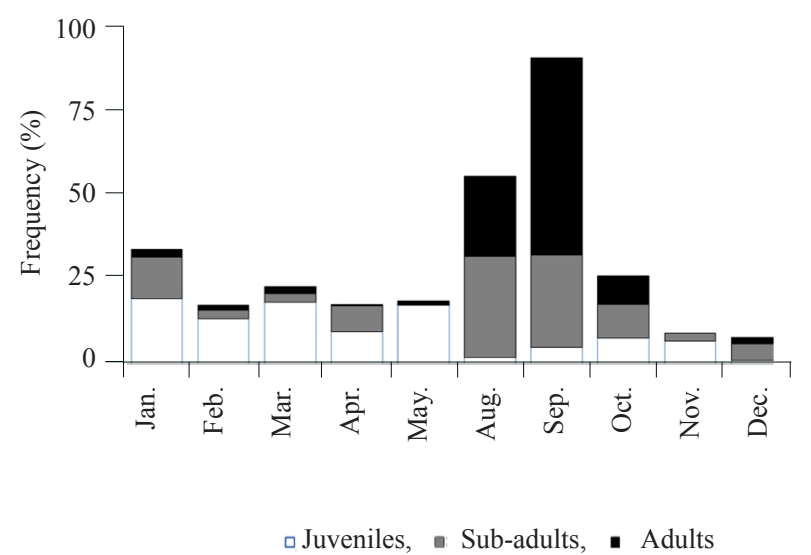

(a)

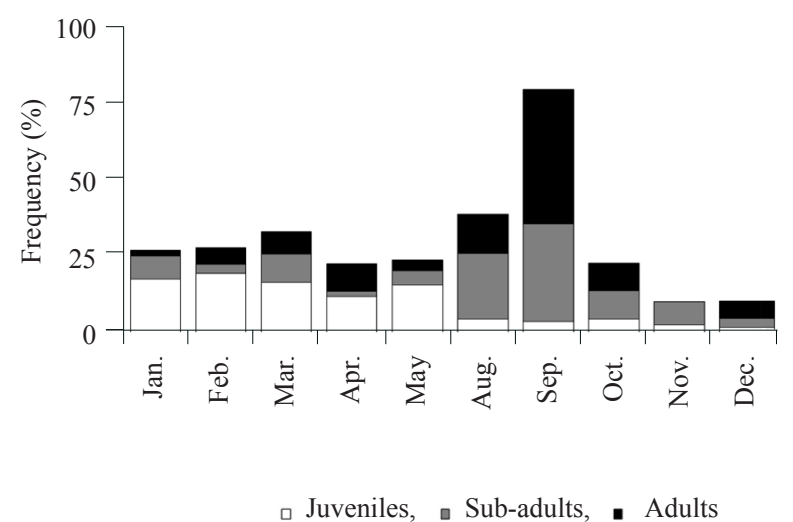

(b)

Fig. 4. Monthly frequency of occurrence of $R$. annandalei sampled from Maharashtra between January 2012 to December 2016 (Pooled data) for (a) female and (b) male 


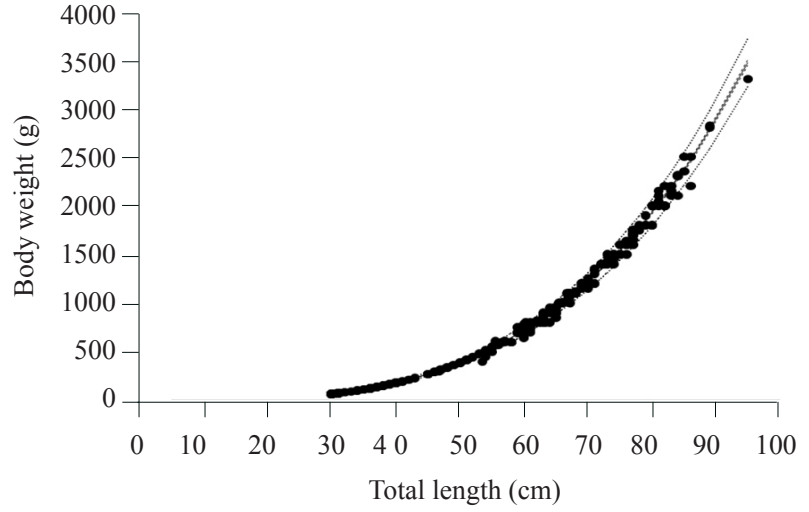

(a)

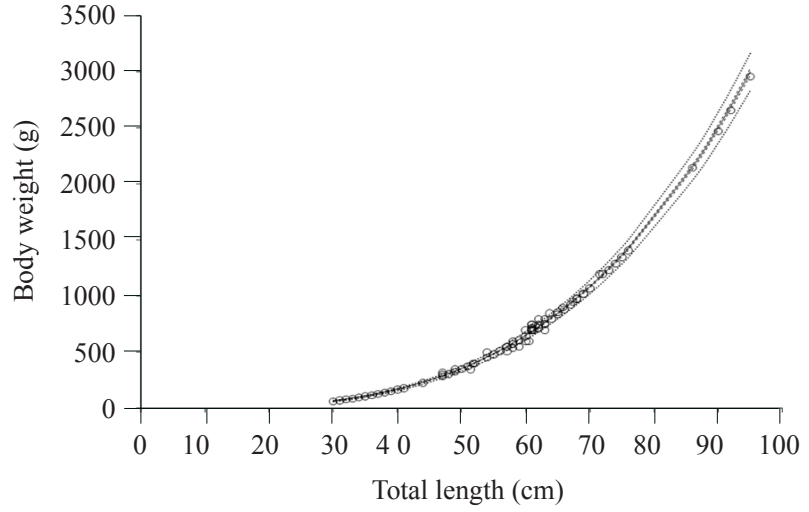

(b)

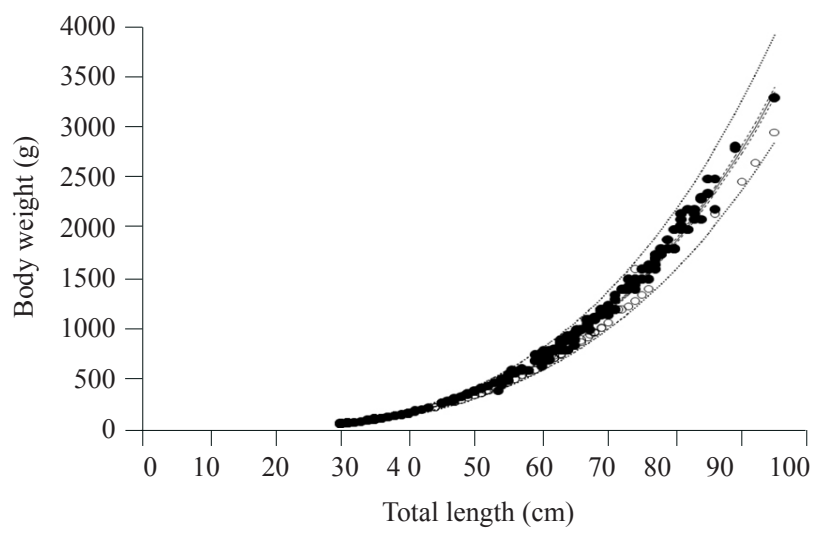

(c)

Fig. 5. Length-weight (TL-TW) relationship of R. annandalei for (a) female (b) male and (c) combined sex. Plots are mean body weight at length (-) with $95 \%$ confidence intervals $(---), 95 \%$ prediction intervals $(\ldots)$ and raw data - females $(\bullet)$ and males $\left({ }^{\circ}\right)$

$(n=108)$ contained trace contents only and $5.6 \%(n=12)$ were full. The prey items were recognised in females and males of length range $70.0 \mathrm{~cm}-95.0 \mathrm{~cm} \mathrm{TL}(n=107)$ and were analysed for IRI. Analysis of the stomach contents (\%IRI) revealed that $R$. annandalei fed primarily on

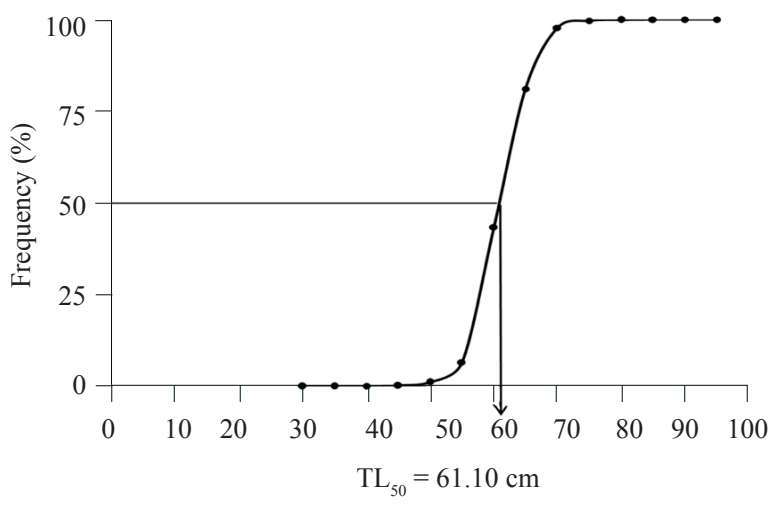

(a) crustaceans $(66.5 \%)$, teleosts $(33.1 \%)$ and cephalopods $(0.4 \%)$. The major prey items included Solenocera spp. (\%IRI=18.7), Parapenaeopsis sculptilis (\%IRI=0.5), Parapenaeopsis stylifera $(\% \mathrm{IRI}=0.4)$ and sciaenids $(\%$ IRI $=0.4)($ Table 2$)$.

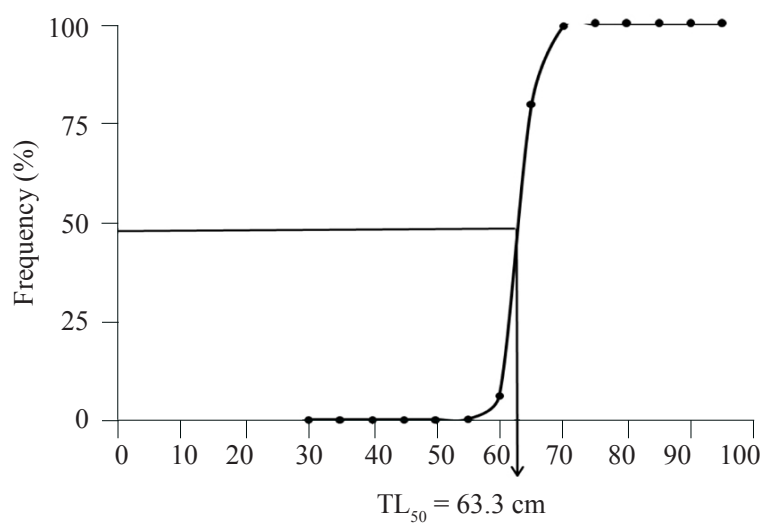

(b)

Fig. 6. Length at maturity of R. annandalei (a) female and (b) male. Arrows indicate the TLat which $50 \%$ of females and males attain maturity $\left(\mathrm{TL}_{50}\right)$. 


\section{Discussion}

The present study provides essential information on the reproductive biology, length at maturity, length-weight relationship and diet of the sparsely studied Bengal guitarfish, $R$. annandalei found in the northern Indian Ocean. A continuous survey of the biodiversity, biology and fisheries of the north-eastern Arabian Sea elasmobranchs provided new information on the sharklike batoid fauna of the region. The nine shark-like batoid species recorded in this study are classified in the IUCN Red List as Data Deficient, Vulnerable and Critically Endangered or Not Evaluated due to lack of taxonomic clarification and are therefore, not evaluated (IUCN, 2018). Rhinobatos annandalei was often misidentified as Rhinobatos punctifer in the Arabian Sea and adjacent waters for a long time until Last et al. (2016) and Jabado (2018) drew attention to the fact. $R$. punctifer was described by Compagno and Randall (1987) as being found in the Gulf of Aqaba in the northern Red Sea. By and large, $R$. annandalei can be observed in both the east and west coasts of India (Talwar and Kacker, 1991).

Though $R$. annandalei is common in the fishery along the southern and eastern coast of India, its documentation is limited and mostly unreported from many regions. Species-specific life history traits are essential for making any assessment or management recommendations. The size range of $R$. annandalei observed in the trawl/gill net/ bag or $d o l$ net fishery of the northern Arabian Sea (30.0$95.0 \mathrm{~cm} \mathrm{TL}$ ) differed from those reported from other regions. Vossoughi and Vosoughi (1999) recorded a single specimen in the Persian Gulf and the Sea of Oman. Jabado (2018) examined 42 specimens of both sexes (40.4-86.5 $\mathrm{cm}$ TL) in the UAE and Oman. Raje (2006) and Raje et al. (2007) observed 452 individuals measuring upto $85.0 \mathrm{~cm}$ TL, while Raje et al. (2012) studied 365 specimens (27.0-85.0 cm TL for females and 30.0-74.0 cm TL for males) and Gladston et al. (2018) examined 13 specimens (34.0-65.0 cm TL for females and 46.0-89.0 cm TL for males) in Mumbai waters. Furthermore, the present study has recorded the longest TL for $R$. annandalei $(95.0 \mathrm{~cm} \mathrm{TL})$ to date. These differences could be the result of several factors like fishing gear selectivity and/ or sample size and regional differential growth based on habitat (Motta et al., 2005). The difference detected between size-frequency distribution of females and males is probably a consequence of sexual segregation, a general characteristic of elasmobranchs that is normally associated with reproduction, sex-specific migration into inshore waters or competition and season (Ford, 1921; Steven, 1933; Springer, 1967; Klimley, 1987; Stevens and Mcloughlin, 1991; Motta et al., 2005; Mucientes et al., 2009; Wearmouth and Sims, 2010).

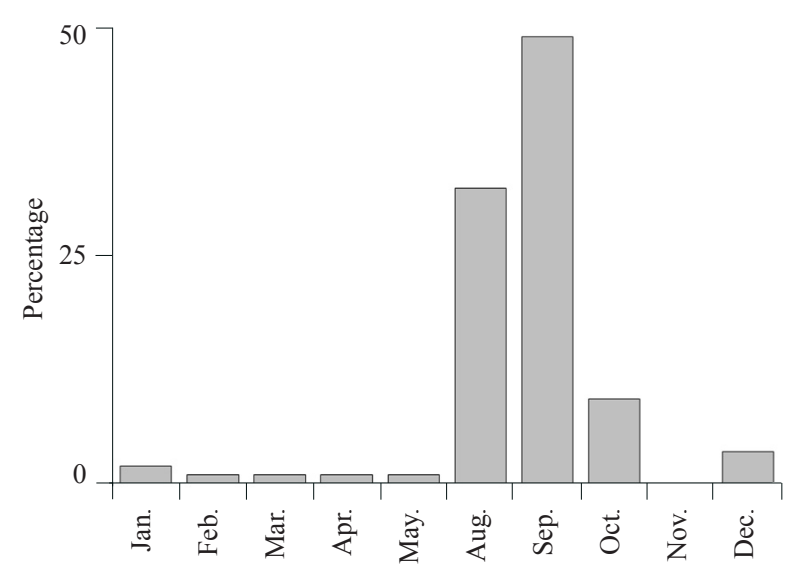

Fig. 7. Percent frequency of occurrence of pregnant females of R. annandalei

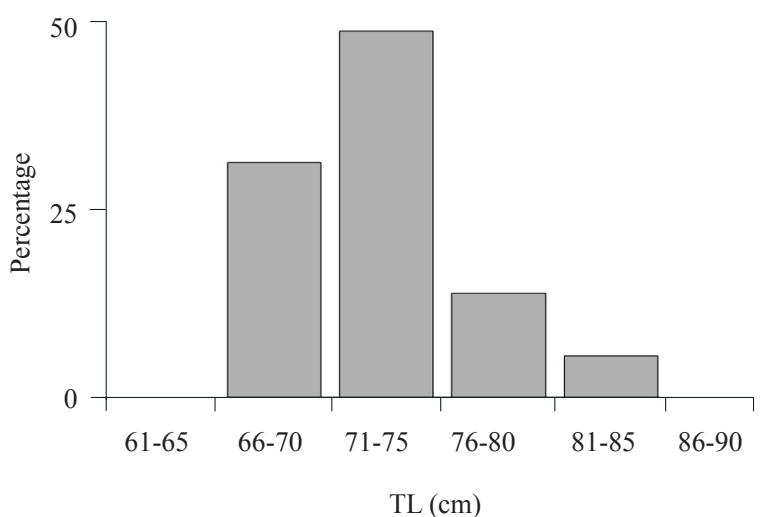

Fig. 8. Total length (TL)-frequency histogram of pregnant R. annandalei

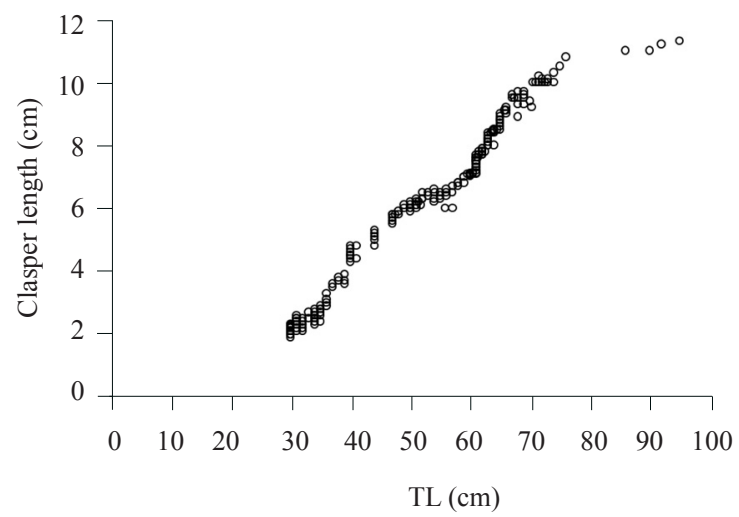

Fig. 9. Relationship between outer clasper length (OCL) and total length of males of $R$. annandalei 
There is no published information available on biology of $R$. annandalei and much of the batoid literature in the region is a decade old (Raje, 2006; Raje et al., 2007). The overall sex ratio of females to males recorded from the landings (1.6:1), showed sexual segregation in this species in the north-eastern Arabian Sea and unequal trends in monthly sex ratios. The seasonal and size-class sex ratio analyses indicated that the juveniles, sub-adults and adults of $R$. annandalei showed sex and size segregation. However, observations by Raje (2006) indicated that females and males were unequally distributed in the fishery during 1989-2003 and the sex ratio to be 1.2:1. Raje et al. (2012) made a similar observation regarding female to male ratio as 1.2:1 based on 365 specimens for 1999-2005 from Mumbai. White and Dharmadi (2007) analysed the sex ratio of 6 of the 54 species of batoids, which differed significantly from parity in eastern Indonesia and more females were observed in the sampling of Rhynchobatus australiae, Dasyatis cf. kuhlii (Java form), Gymnura poecilura, Dasyatis zugei, Himantura jenkinsii and Pteroplatytrygon violacea. Similarily, Rhinobatos jimbaranensis showed skewed sex ratio (1.4:1) with female dominance in the landings, whereas Rhinobatos penggali showed sex ratio of 0.97:1. Jabado (2018) recorded female to male ratio as 1.1:1 based on 42 specimens of $R$. annandalei for 2010-2012 from the Arabian Sea and adjacent waters. In the same genera, Farrugia et al. (2011) recorded abundance, habitat use and movement patterns of Rhiobatos productus in a restored southern California estuary and found no evidence of sexual segregation by season based on the sex ratio of the catch. Unequal sex ratios can be the result of sexual segregation by depth or area and/or gear selectivity (Akhilesh et al., 2013).

In the present study, the length-weight relationship (TL $v s$.TW) of $R$. annandalei was significantly different between the sexes. Raje et al. (2007) estimated co-efficients
' $a$ ', and ' $b$ ' of the length-weight relationship as -4.3293 and $2.9568(\mathrm{r}=0.91, n=179)$ for females and -3.6020 and $2.3234(\mathrm{r}=0.8, n=85)$ for males. Gladston et al. (2018) reported length-weight relationship (combined sexes) as $\mathrm{W}=0.0012 * L^{3.2099}\left(\mathrm{r}^{2}=0.9871, n=13\right)$. Co-efficients ' $a$ ' and ' $b$ ' of the length-weight relationship were estimated to be 0.0034 and $3.1946\left(\mathrm{r}^{2}=0.9991, n=5\right)$ for females and 0.0014 and $3.1795\left(r^{2}=0.9740, n=8\right)$ for males in the northeastern Arabian Sea. On the contrary, the observations of the present study indicated that females and males followed allometric growth $b>3$ (the fish grows faster in weight than in length) in the same study area. According to Stevens and Wiley (1986), these variations between length-weight relationships of females and males could be a result of different sample sizes, unequal distribution of sizes within each dataset of each sex or even of non-pregnant females being lighter due to inclusion of spent fish, which have a lower condition factor.

The $\mathrm{TL}_{50}$ of females at maturity determined in the present study was $61.9(60-65) \mathrm{cm}$ TL for $R$. annandalei. Information on the length at maturity for females of $R$. annandalei is limited. However, the observation made by Raje (2006) indicated that mature females observed during 1989-2003 period was $60 \mathrm{~cm}$ TL, while Raje et al. (2012) on studying the breeding behaviour of elasmobranchs in Mumbai waters, recorded the lowest length of a mature female $R$. annandalei to be $59.0 \mathrm{~cm} \mathrm{TL}$.

There is paucity of data on length at maturity of male $R$. annandalei, as smallest adult male observed in the present study was $61 \mathrm{~cm}$ TL, while the smallest adult male observed by Raje (2006) and Raje et al. (2012) was $50 \mathrm{~cm}$ $\mathrm{TL}$. The $\mathrm{TL}_{50}$ of males at maturity estimated in the present investigation, was $63.3(60-65) \mathrm{cm} \mathrm{TL}$, but Last et al. (2016) reported that $R$. annandalei matured at $68.0 \mathrm{~cm}$ TL (males). In the same genus, White and Dharmadi (2007) reported that $R$. jimbaranensis and $R$. penggali males matured at $76.5 \mathrm{~cm}$ TL and $71.9 \mathrm{~cm}$ TL, respectively, in

Table 2. Prey composition of R. annandalei from Maharashtra, north-west coast of India

\begin{tabular}{|c|c|c|c|c|}
\hline Prey item & $\% \mathrm{~N}$ & $\% \mathrm{M}$ & $\% \mathrm{O}$ & $\%$ IRI \\
\hline \multicolumn{5}{|l|}{ Crustacea } \\
\hline Solenocera spp. & 31.5 & 30.3 & 15.4 & 18.7 \\
\hline Parapenaeopsis stylifera & 5.6 & 1.7 & 2.6 & 0.40 \\
\hline Parapenaeopsis sculptilis & 1.9 & 7.9 & 2.6 & 0.50 \\
\hline Crabs & 1.9 & 1.3 & 2.6 & 0.20 \\
\hline Squilla spp. & 1.9 & 1.7 & 2.6 & 0.20 \\
\hline Other unidentified shrimp & 29.6 & 32.0 & 38.5 & 46.6 \\
\hline \multicolumn{5}{|l|}{ Mollusca } \\
\hline Loligo spp. & 3.7 & 3.5 & 2.6 & 0.40 \\
\hline \multicolumn{5}{|l|}{ Teleostei } \\
\hline Sciaenids & 1.9 & 3.8 & 2.6 & 0.30 \\
\hline Other unidentified fishes & 22.2 & 32.0 & 30.8 & 32.8 \\
\hline
\end{tabular}


eastern Indonesia. However, the dataset of the present study showed that females and males matured between 60 and $65 \mathrm{~cm}$ TL.

Further, the examination of a large number of pregnant females $(n=108)$, showed that this species had a mean number of two embryos (ranging between 2-11) and size at birth ranged between 25.0 and $30.0 \mathrm{~cm}$ TL. Raje (2006) recorded the maturity status of nine female $R$. annandalei and set forth the common number of young ones produced at a time as eight (four from either uterus), although the maximum recorded was twenty, and length at birth as $11.5 \mathrm{~cm}$ to $22.3 \mathrm{~cm}$ TL. The present study recorded specimens measuring $>30.0 \mathrm{~cm}$ TL only in the fishery.

Pregnant females examined during pre-monsoon, monsoon and post-monsoon showed a wide range of embryonic developmental stages, i.e., from fertilised eggs to late-term embryos and appeared to have a non-seasonal reproductive cycle. The presence of fertilised eggs and embryos found in the uterus of some females indicated probable reproductive activity associated with coastal feeding as well as pupping in the coastal waters. According to Smith (1961), a fair number of mature females of Rhinobatos annulatus seggregated in the estuaries for pupping. Raje (2006) stated that the greatest reproductive activity appeared to be during the monsoon and post-monsoon months, as maximum gravid or parturient females were landed in September and October. Therefore, the parturition period appeared to be towards the end of the year and changes in the landings of juveniles measuring $<50.0 \mathrm{~cm}$ TL during January to May explicitly support the observation made during the present study. Raje et al. (2007) reported the peak breeding season for the species as between September-October in the north-west coast of India and between August-November in south-west coast of India.

Previously, only a few reports provided basic information on the diet of this species. Raje (2006) suggested that $R$. annandalei fed on fishes (Harpadon nehereus, Cynoglossus spp., Priacanthus hamrur and Trichiurus spp.) and crustaceans (prawns and squilla). In the present study, $R$. annandale $i$ was found to feed primarily on crustaceans $(66.5 \%)$, teleosts $(33.1 \%)$ and cephalopods $(0.4 \%)$. Its major prey items included Solenocera spp. $(\% \mathrm{IRI}=18.7)$, P. sculptilis $(\% \mathrm{IRI}=0.5)$, $P$. stylifera $(\% \mathrm{IRI}=0.4)$ and sciaenids $(\% \mathrm{IRI}=0.4)$. The results indicated $R$. annandalei as a mesopredator that displayed both benthic and demersal feeding behaviour with a diet consisting predominantly of invertebrates. The typical coastal prey items found in the stomachs revealed that $R$. annandalei inhabited depths between 2-70 $\mathrm{m}$.
A large scale survey of elasmobranchs in general and shark-like batoids in particular, is essential to document their level of susceptibility to being captured in a variety of fishing gears operating in particular geographical areas. Many guitarfish species are hindered by identification challenges and as indicated by the often outdated IUCN Red List assessments, the vast majority of guitarfishes are threatened, poorly known or both (Moore, 2017). The results of the present study will contribute significantly to an understanding of the species composition and exploitation in the trawl, gillnet and $\mathrm{dol} / \mathrm{bag}$ net fisheries of Maharashtra, India. The study provides the first ever detailed information on biological observations including size and sex compositions, maturity, diet, length-weight relationship and occurrence of $R$. annandalei and also details of bycatch of this species from inshore fisheries operating off the north-west coast of India at depths of 2-70 m. The study documented the landing of sharklike batoids in multispecies and multi-gear regime in the region; the frequency of occurrence and the quantity of landings indicated the population size structure, demography (age at maturity and fecundity) and species abundance (Walker, 1998; Jabado, 2018). The biological knowledge of chondrichthians in Indian waters is not well documented and information is scarce (Akhilesh et al., 2013, Purushottama et al., 2018). The data on life history is very important for developing species specific management plans aimed at a precautionary approach to ecosystem based management and conservation of sharklike batoids, especially taking into account their role in the marine food web (Stevens et al., 2000; Mulas et al., 2015). Innovative approaches to conservation of guitarfish and elasmobranchs in the inshore areas of the developing world is required to ensure their long term survival (Moore, 2017).

\section{Acknowledgments}

Authors are thankful to the Director, ICAR-CMFRI, Kochi for the support and the facilities provided. Mr. B. B. Chavan and Mr. B. N. Katkar, ICAR-CMFRI, Mumbai are acknowledged for the support in the field and laboratory. We thank the fishers and traders who allowed for data to be collected along Maharashtra coast and for their friendship, cooperation and support.

\section{References}

Akhilesh, K. V., White, W. T., Bineesh, K. K., Ganga U. and Pillai, N. G. K. 2013. Biological observations on the bristly catshark Bythaelurus hispidus from deep waters off the south-west coast of India. J. Fish Biol., 82: 1582-1591. doi: $10.1111 / \mathrm{jfb} .12087$.

Alagaraja, K. 1984. Simple methods for estimation of parameters for assessing exploited fish stocks. Indian J. Fish., 31(2): 177-208. 
Biradar, R. S. 2002. Course manual: Fisheries Statistics, $2^{\text {nd }}$ edn. ICAR-Central Institute of Fisheries Education, Mumbai, India, $246 \mathrm{pp}$.

CMFRI 2013. Annual report 2012-13. ICAR-Central Marine Fisheries Research Institute, Kochi, 200 pp.

CMFRI 2014. Annual report 2013-14. ICAR-Central Marine Fisheries Research Institute, Kochi, 274 pp.

CMFRI 2015. Annual report 2014-15. ICAR-Central Marine Fisheries Research Institute, Kochi, 353 pp.

CMFRI 2016. Annual report 2015-16. ICAR-Central Marine Fisheries Research Institute, Kochi, 294 pp.

Cochran, W. G. 1952. The $\chi^{2}$ test of goodness of fit. Ann. Math. Stat., 25: 315-345.

Compagno, L. J. V. and Randall, J. E. 1987. Rhinobatos punctifer, a new species of guitarfish (Rhinobatiformes: Rhinobatidae) from the Red Sea, with notes on the Red Sea batoid fauna Proc. Calif. Acad. Sci., 44: 335-342.

Cortes, E. 1997. A critical review of methods of studying fish feeding based on analysis of stomach contents: application to elasmobranch fishes. Can. J. Fish. Aquat. Sci., 54: 726 -738. DOI: 10.1139/cjfas-54-3-726.

Dulvy, N. K., Fowler, S. L., Musick, J. A., Cavanagh, R. D., Kyne, P. M., Harrison, L. R., Carlson, J. K., Davidson, L. N. K., Fordham, S. V., Francis, M. P., Pollock, C. M., Simpfendorfer, C. A., Burgess, G. H., Carpenter, K. E., Compagno, L. J. V., Ebert, D. A., Gibson, C., Heupel, M. R., Livingstone, S. R., Sansciangco, J. C., Stevens, J. D., Valenti, S. and White, W. T. 2014. Extinction risk and conservation of the world's sharks and rays. eLife 3: e00590.

Farrugia, T. J., Espinoza, M. and Lowe, C. G. 2011. Abundance, habitat use and movement patterns of the shovelnose guitarfish (Rhinobatos productus) in a restored southern California Estuary. Mar. Freshw. Res., 62: 648-657.

Ford, E. 1921. A contribution to our knowledge of the lifehistory of the dogfishes landed at Plymouth. J. Mar. Biol. Ass. UK, 12: 468 -505.

Froese, R. 2006. Cube law, condition factor and weight-length relationships: history, meta-analysis and recommendations. J. Appl. Ichthyol., 22: 241-253. DOI: 10.1111/j.14390426.2006.00805.x.

Gladston, Y., Akhilesh, K. V., Thakurdas, C., Ravi, O. P. K., Ajina, S. M. and Shenoy, L. 2018. Length-weight relationship of selected elasmobranch species from northeastern Arabian Sea, India. J. Appl. Ichthyol., 34(3): 753-757. https://doi. org/10.1111/jai.13680.

IUCN 2018. The IUCN Red List of Threatened Species. Version 2018-3. http://www. iucnredlist.org (Accessed 30 August 2018)

Jabado, R. W. 2018. The fate of the most threatened order of elasmobranchs: Shark-like batoids (Rhinopristiformes) in the Arabian Sea and adjacent waters. Fish. Res., 204: 448-457. https://doi.org/10.1016/j.fishres.2018.03.022.

Jabado, R. W., Kyne, P. M., Pollom, R. A., Ebert, D. A., Simpfendorfer,C.A.,Ralph,G.M.,AlDhaheri,S.S.,Akhilesh, K. V., Ali, K., Ali, M. H., Al Mamari, T. M. S., Bineesh, K. K., El Hassan, I. S., Fernando, D., Grandcourt, E. M., Khan, M. M., Moore, A. B. M., Owfi, F., Robinson. D. P., Romanov, E., Ana-Lucia, S., Spaet, J. L. Y., Tesfamichael, D., Valinassab, T. and Dulvy, N. K. 2018. Troubled waters: Threats and extinction risk of the sharks, rays and chimaeras of the Arabian Sea and adjacent waters. Fish Fish., 19(6): 1043 -1062. doi:10.1111/faf.12311.

Jabado, R. W., Kyne, P. M., Pollom, R. A., Ebert, D. A., Simpfendorfer, C. A., Ralph, G. M. and Dulvy, N. K. 2017. The conservation status of sharks, rays, and chimaeras in the Arabian Sea and adjacent waters. IUCN Species Survival Commission Shark Specialist Group, Environment Agency, Abu Dhabi, Vancouver, Canada, $236 \mathrm{pp}$.

Klimley, A. P. 1987. The determinants of sexual segregation in the scalloped hammerhead shark Sphyrna lewini. Environ. Biol. Fish., 18 (1): 27-40. DOI: 10.1007/BF00002325.

Last, P. R., White, W. T., de Carvalho, M. R., Seret, B., Stehmann M. F. W. and Naylor, G. J. P. 2016. Rays of the world. CSIRO Publishing, Clayton, Australia and Cornell University Press (Comstock Publishing Associates), Ithaca, New York, USA, i-ix + 790 pp.

Le Cren, E. D. 1951. The length-weight relationship and seasonal cycle in gonad weight and condition in the perch (Perca fluviatilis). J. Anim. Ecol., 20: 201-219. DOI: 10.2307/1540.

Montgomery, D. C., Peck, E. A. and Vining, G. G. 2012. Introduction to linear regression analysis, $5^{\text {th }}$ edn. Wiley Publication, New Jersey, USA, 688 pp.

Moore, A. B. M. 2017. Are guitarfishes the next sawfishes? Extinction risk and an urgent call for conservation action. Endang. Sp. Res., 34: 75-88. https://doi.org/10.3354/ esr00830.

Moore, A. B. M., McCarthy, I. D., Carvalho, G. R. and Peirce, R. 2012. Species, size, sex and male maturity composition of previously unreported elasmobranch landings in Kuwait, Qatar and Abu Dhabi Emirate. J. Fish Biol., 80: 1619-1642. https://doi.org/10.1111/j.1095-8649.2011.03210.x,.

Motta, F. S., Gadig, O. B. F., Namora, R. C. and Braga, F. M. S. 2005. Size and sex compositions, length-weight relationship and occurrence of the Brazilian sharpnose shark, Rhizoprionodon lalandii, caught by artisanal fishery from southeastern Brazil. Fish. Res., 74: 116-126.

Mucientes, G. R., Queiroz, N., Sousa L. L., Tarroso P. and Sims D. W. 2009. Sexual segregation of pelagic sharks and the potential threat from fisheries. Biol. Lett., 5: 156 -159. doi: 10.1098/rsbl.2008.0761. 
Mulas, A., Bellodi, A., Cannas, R., Cau, Al. Cuccu, D., Marongiu, M. F., Porcu, C. and Follesa, M. C. 2015. Diet and feeding behaviour of longnosed skate Dipturus oxyrinchus. J. Fish Biol., 86: 121-138. doi:10.1111/jfb.12551.

Pinkas, L., Oliphant, M. S. and Iverson, I. L. K. 1971. Food habits of albacore, bluefin tuna and bonito in California waters. Cal. Fish Game, 152: 1-105.

Purushottama, G. B., Thakurdas, Tandel, S. S., Mhatre, V. D. and Singh, V. V. 2018. Records of rare elasmobranchs and their biological observation from the north-eastern Arabian Sea, off Mumbai. Indian J. Mar. Sci., 47(8): 1566-1573.

Purushottama, G. B., Thakurdas, Ramasubramanian, V., Gyanaranjan, D., Akhilesh, K. V., Ramkumar, S., Kizhakudan, S. J., Singh, V. V. and Zacharia, P. U. 2017. Reproductive biology and diet of grey sharpnose shark Rhizoprionodon oligolinx Springer, 1964 (Chondrichthyes: Carcharhinidae) from the north-eastern Arabian Sea. Indian J. Fish., 64(4): 9-20. doi: 10.21077/ ijf.2017.64.4.63379-02.

Raje, S. G., Thakurdas and Sujit, S. 2012. Relationship between body size and certain breeding behaviour in selected species of elasmobranchs off Mumbai. J. Mar. Biol. Ass. India, 54 (2): 85-89, doi: 10.6024/jmbai.2012.54.2.01691-14.

Raje, S. G., Sivakami, S., Mohan Raj, G., Manoj Kumar, P. P., Raju, A. A. and Joshi, K. K. 2007. An atlas on the elasmobranch fishery resources of India. Special Publication No. 95, ICAR-Central Marine Fisheries Research Institute, Kochi, India,, 253 pp.

Raje, S. G. 2006. Skate fishery and some biological aspects of five species of skates off Mumbai. Indian J. Fish., 53(4): 431-439.

Smith, J. L. B. 1961. The sea fishes of Southern Africa. Central News Agency Ltd., Johannesburg, South Africa, 573 pp.

Springer, S. 1967. Social organisation of shark populations. In: Gilbert, P. W., Mathewson, R. F. and Rall, D. P. (Eds.), Sharks, skates and rays. John Hopkins University Press, Baltimore, USA, p. 149-174.

Stehmann, M. F. W. 2002. Proposal of a maturity stages scale for oviparous and viviparous cartilaginous fishes (Pisces, Chondrichthyes). Arch. Fish. Mar. Res., 50: 23-48.

Steven G. A. 1933. Rays and skates of Devon and Cornwall, III. The proportions of the sexes in nature and in commercial landings and their significance to the fishery. J. Mar. Biol. Ass. UK, 18: 611-625.

Stevens, J. D., Bonfil, R., Dulvy, N. K. and Walker, P. A. 2000. The effects of fishing on sharks, rays and chimaeras (chondrichthyans) and the implications for marine ecosystems, ICES J. Mar. Sci., 57: 476-494. https://doi. org/10.1006/jmsc.2000.0724.

Stevens, J. D. and Mcloughlin, K. J. 1991. Distribution, size and sex composition, reproductive biology and diet of sharks from northern Australia. Aust. J. Mar. Freshw. Res., 42: 151-199.

Stevens, J. D. and Wiley, P. D. 1986. Biology of two commercially important Carcharhinidae sharks from northern Australia. Aust. J. Mar. Freshw. Res., 37: 671-688.

Talwar, P. K. and Kacker, R. K. 1984. Commercial sea fishes of India. Zoological Survey of India, Calcutta, India, 997 pp.

Valenti, S. V. 2009. Rhinobatos annandalei. The IUCN Red List of Threatened Species 2009: e.T161478A5432942. http:// dx.doi.org/10.2305/IUCN.UK.20092.RLTS. T161478A5432942.en. (Accessed 05 November 2018).

Vossoughi, G. H. and Vosoughi, A. R. 1999. Study of batoid fishes in northern part of Hormoz Strait, with emphasis on some species new to the Persian Gulf and Sea of Oman. Indian J. Fish., 46(3): 301-306.

Walker, T. I. 1998. Can shark resources be harvested sustainably? A question revisited with a review of shark fisheries. Mar. Freshw. Res., 49: 553-572.

Wearmouth, V. J. and Sims, D. W. 2010. Sexual segregation in elasmobranchs. Biol. Mar. Mediterr., 17(1): 236-239.

White, W. T. 2007. Catch composition and reproductive biology of whaler sharks (Carcharhiniformes: Carcharhinidae) caught by fisheries in Indonesia. J. Fish Biol., 71 (5): 1512 1540. doi: 10.1111/j/1095-8649.2007.01623.x.

White, W. T. and Dharmadi 2007. Species and size composition and reproductive biology of rays (Chondrichthyes, Batoidea) caught in target and non-target fisheries in eastern Indonesia. J. Fish Biol., 70: 1809-1837. doi: 10.1111/j/1095-8649.2007.01458.x.

Wood, M. 2004. Statistical inference using bootstrap confidence intervals. Significance, 1: 180-182. https://doi. org/10.1111/j. 1740-9713.2004.00067.x. 